\title{
Violation of Politeness Principle On Students Speech In Multicultural Society: Sosiopragmatic Study
}

\author{
Afif Restu Fauzi ${ }^{1}$, Ida Zulaeha ${ }^{2}$ and Rahayu Pristiwati ${ }^{3}$ \\ \{Afifrfauzi@ymail.com¹, idazulaeha@mail.unnes.ac.id², rahayuprstiwati@yahoo.co.id ${ }^{3}$ \} \\ Graduate School, Universitas Negeri Semarang, Indonesia ${ }^{1,2,3}$
}

\begin{abstract}
Students at Al Asror MTs get special lessons about good morals. Ideally, all utterances obey the rules of politeness. However, it is often found students who are suspected of violating the rules of politeness. Allegedly, violations are motivated by nonlinguistic factors. This study aims to analyze and explain the factors that cause violations of politeness in student speech in multicultural societies. This approach uses a pragmatic and descriptive qualitative approach. Data collection using the method of refer to and capable. Data analysis uses the pragmatic equivalent method. The results of the analysis showed 45 speeches violated the tact maxim; 10 speeches violating the generosity maxim; 13 speeches violating the approbation maxim; 24 speeches violating the agreement maxim; 26 speeches violate the modesty maxim; and 7 speeches violating the simpathy maxim. Violations are motivated by non-linguistic factors, namely social, geographical, social distance between speakers, family, and psychological.
\end{abstract}

Keywords: violation of politeness, multicultural society, sociopragmatics

\section{Introduction}

Politeness is a strategy to avoid friction and conflict in social interaction. Through polite language, speakers and speech partners can avoid friction in interpersonal interactions. Politeness is also a strategy to avoid conflict, maintain and maintain respect. This was confirmed by Rohali "The application of politeness principles and politeness strategies in daily speech acts can prevent social friction and turmoil in the community which ultimately creates harmony in family life, friends, and society" [1]. Zulaeha argues that misunderstandings and disharmony of relationships can be caused by incorrect selection and use of language [2]. Thus, modestly speaking politeness is closely related to 'respect' or at least places someone where he wants [3].

MTs Al Asror is an Islamic boarding school-based Islamic education institution. In terms of speakers, students at this institution get special lessons about good morals, such as Aqeedah, Ahlak, Worship, KeNUan, SKI, Quran Hadith, and Fiqh. Ideally, all utterances that are used in communicating at institutions adhere to the rules of politeness. However, students are still often suspected of violating politeness rules in social interaction in the school environment. This is proven by the fact that students still communicate poorly, such as cursing, insulting, and ridiculing.

The use of students' bad utterances does not just appear but rather because of the underlying factors, both linguistic and non-linguistic factors. Allegedly, the factor underlying MTs Al Asror 
students violates the principle of politeness in language from the point of view of language users in sociopragmatic studies, namely the non-linguistic factor. These non-linguistic factors are social, geographical, social distance between speakers, family, and psychological. Rokhman argues that the use of language in society according to a sociolinguistic perspective is influenced by several factors, for example the factors of relations between speakers and speech partners, social, cultural, and situation factors [4]. Based on this, the researcher is interested in analyzing and explaining the factors underlying the violation of politeness principles in student speech in the context of multicultural society in the MTs Al Asror environment.

\section{Method}

This research uses a pragmatic and descriptive qualitative approach. The data in this study are (1) fragments of conversations between students and teachers suspected of containing violations of the politeness principle, (2) information on social, geographical factors, social distance between speakers, family, and psychological factors in the background of violations of politeness principles, and (3) data field notes namely descriptive and reflective field notes. Data collection is done by listening and observing methods. Data analysis was performed using the pragmatic matching method with the basic techniques of determining the determinants and advanced techniques.

\section{Result and Discussion}

\subsection{Form of Violation of the Politeness Principle in Student Speech in Multicultural Communities}

Based on the analysis, found violations of politeness in thimbles rather than rationality, generosity, acceptance, modesty, approval, and conclusions. Violations occur when students interact in stalls, during recess, and during the learning process in class. Following is the discussion of politeness thimble violations in students' speeches.

Violation of Tact Maxim. The principle of the tact maxim is how the other party is burdened with the least light costs with maximum profit in the speech.

(1) CONTEXT: AFTER THE RETURN OF THE SCHOOL, IN THE SIDE OF THE SCHOOL OF THE SIDE OF SCHOOL STUDENT A, WHICH COMES FROM ACEH REGION INVOLVING STUDENT B AND C PLAYING SOCCER

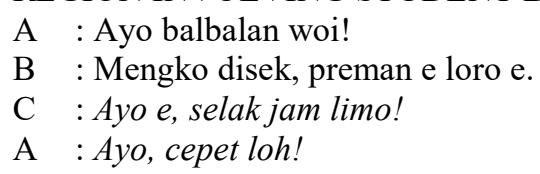

Student $\mathrm{C}$ in the speech 'Ayo e, selak jam limo!' violates the tact maxim. This is because speech partners are burdened with large costs with little profit. Likewise, student A in 'Ayo, cepet loh!'Violates the thimble instead of the sensation because the speaker seems to maximize profits to himself, and maximize losses to the speech partner. 
Violation of Generosity Maxim. The principle of generosity maxim is how the speech partner in the speech is strived to get the maximum profit, meanwhile, yourself trying to get the smallest profit.

(2) CONTEXT: WHEN RETURNING SCHOOL ON THE PAGE OF SCHOOL STUDENT A ASK TO STUDENT B, THEN STUDENT A REPORTED TO THE MANAGER OF HOSPITALS WITH THE CONSIDERATION THAT A STUDENT HAS MEETED WITH ONE OF THE DAUGHTERS 'STUDENTS

A : hayo, bar ko ndi kui? Ketemuan ya?

B : biasa ta, cah enom.

A : Kang, iki bar ketemuan mbe mbak pondok.

Student B's speech "biasa ta, cah enom" violates the generosity maxim, because the speaker seems to maximize profits to himself and minimize profits to other parties, so the speech partner in the speech is harmed by the speaker.

Violation of approbation maxim. The principle of approbation maxim is to minimize the criticism of the other party and maximize the praise of the other party.

(3) CONTEXT: WHEN RETURNING SCHOOL ON THE PAGE OF SCHOOL STUDENT A ASK TO STUDENT B, THEN STUDENT A REPORTED TO THE MANAGER OF HOSPITALS WITH THE CONSIDERATION THAT A STUDENT HAS MEETED WITH ONE OF THE DAUGHTERS 'STUDENTS

A : kang, iki bar ketemuan mbe mbak pondok.

$\mathrm{B}$ : piye, cah cilik e.

A : opo kowe, hulk!

Student B in the speech 'piye, cah cilik $e^{\prime}$ and the speech of student A 'opo kowe, Hulk!' violates the approbation maxim. This is because speakers maximize discourse against other parties. Student B uses the word 'cah cilik' and is intended as an explanation for the speaking partner. Furthermore, student A who did not receive the speech responded by using the word 'Hulk' to maximize speaking to student B.

Violation of Agreement Maxim. The principle of agreement maxim is to minimize disagreement between yourself and other parties and maximize agreement between yourself and other parties.

(4) CONTEXT: IN THE SCHOOL PAGE OF STUDENT A TAKES FRIENDS TO PLAY SOCCER. STUDENT B REFUSES A TEACHER, STUDENT C FROM ACEH AGREE TO THE TEACHER, AND STUDENT D REFUSES TEACHER A

A : Balbalan, ayo?

B : Wegah, ana sing beling.

C : Opo ana sing beling, ee keplak'i bareng-bareng!

A : Asyyiaaappp

The words 'Wegah, ana sing beling' violates the agreement maxim because the speaker maximizes antipathy and minimizes agreement between himself and the other party. In this case, other parties who offer to play football get rejected from the speaker. When the speaker shows antipathy to the speech partner, the longer the emotional relationship between them. Conversely, to minimize the distance between the speaker and the speech partner, a statement of admiration can be used to the speech partner [5].

Violation of Modesty Maxim. The principle of modesty maxim is how to maximize praise to others, minimize self-praise, and maximize self-defeating. 
(5) CONTEXT: WHEN THE REST OF SCHOOL, IN PONDOK STUDENT PAGE B FROM TEGAL THAT IS IMPLEMENTING THE PUSH UP TAKZIRAN BECAUSE THE STATE EATING..

$\begin{array}{ll}\text { Siswa A } & \text { : Push up ping telu setengah! } \\ \text { Siswa B } & \text { : Ping sepuluh setengah kuat aku! } \\ \text { Siswa A } & \text { : Yowis, ping sewu? } \\ \text { Siswa B } & \text { : Wegah! } \\ \text { Siswa A } & \text { : Jal, ngumbe ngadek meneh! } \\ \text { Siswa B } & \text { : Koe kok ngakon tok ya? }\end{array}$

Student B in the 'Ping sepuluh setengah kuat aku!' violates the modesty maxim, because the speaker maximizes praise to himself and minimizes praise to the other party. The speaker answered the speech of student A who ordered the push up three and a half times, but the speaker replied that more than three and a half times the speaker was able to do it, which is ten and a half times. This gives the impression that the speaker feels stronger and more powerful than others, so that it seems arrogant.

Violation of simpathy maxim. The principle in the simpathy maxim is that the speaker should minimize the antipathy between oneself and the other party and maximize the sympathy of oneself with the other party.

(6) CONTEXT: WHEN THE REST HOURS SOME OF SANTRI STUDENTS ARE BREAKING AT THE PESANTREN IN THE SIDE OF THE SCHOOL. STUDENT B STORIES ABOUT IT TRAVEL TO STUDENTS A AND B
A : Pecis mireng
B : Pecise diiringke ngene iki
C : Wagu ndes, elek!

Student C said 'Wagu ndes, elek!' violated simpathy maxim because the speaker minimizes one's own conclusions with the other party and maximizes the antipathy between oneself and the other party.

\subsection{Factors Underlying Violation of the Politeness Principle in Student Speech in Multicultural Communities}

Based on the sociopragmatic analysis, it was found that non-linguistic factors which lay behind students violated the principle of politeness, namely social, geographical, social distance between speakers, family, and psychological. Based on the social status of the speaker and speech partner, there are a number of factors behind the violation of politeness principles, namely parental education, economic background, and social environment.

(7) CONTEXT: SOME STUDENTS CONVERSE WHEN THE BREAK OF REST IN ADDITION TO SCHOOL. STUDENTS A AND B USING HIGH DIRTY WORDS

A : Wasem, kowe tak pateni tenan kowe ndess!

B : Asu, ngene loh!

C : Osa asu, osa-asu!

B : Eh, mau sing ngonekke Wafa, Ndes!

A : Matamu, ngece, nak diece wegah! 
Student A cursed for expressing anger using vicious words, namely 'Wasem', 'Ndess', and 'Matamu'. Likewise student B, using the heinous words 'Asu' and 'Ndess'. The words used by the speakers of students A and B are felt to be very rude, high-pitched, offensive and maximizing discourse to the speech partner. Violence politeness by students A and B was identified because of two factors. First, judging by association, students A and B often mingle with adults in stalls. In addition, the two students often hang out with senior students. This can be indicated that the more students get along, the more often the conversation, the higher the speaking skills [6]. Second, judging from the history of violations of the rules in the cottage, students A and B often get punishment from security. This is because the two students often violate the rules, namely hanging out at the stall, playing at the internet cafe, and getting caught smoking. Based on the identification, it can be concluded that the speaker violates the politeness principle based on social factors, namely the social environment. The results of Widyawari, May, \& Ida's research also showed that there were social factors behind the politeness violations [7].

Based on geographical location, differences in students of MTs Al Asror include differences in regional origin, dialeg, culture, and community norms. This reinforces the results of Cahyani and Rokhman's research that 'place' is one of the causes of politeness violations [8]. In addition, Rokhman and Indiatmoko also found that culture is one of the causes of politeness violations [9]. Furthermore, the social distance between speakers includes student-student relationships and student-teacher relations, this relates to language users as a measure of how close or far the social relations between speakers and speech partners. Factors underlying the subsequent politeness violations are family factors, including differences in relations between family members and parenting patterns. Furthermore, based on psychological factors of the speaker and the speech partner, violations of the politeness principle in the students' speech are motivated by the emotions of the speech participants. Alika also mentioned that psychiatric factors are one of the causes of politeness violations [10].

(8) CONTEXT: AT THE BREAK OF THE REST, IN THE PONDOK STUDENT'S PAGE B FROM THE TEGAL WHICH IS IMPLEMENTING THE TAKZIRAN PUSH UP BECAUSE THE EATING OF THE SAMBIL'S STANDING IS CONCERNING THE STUDENT A

A : Push up ping telu setengah!

B : Ping sepuluh setengah kuat aku.

A : Yowis, ping sewu?

Student B in the words 'Ping sepuluh setengah kuat aku' intends to show that the speaker is able to do push ups more than three and a half times, which is ten and a half times. This is because (1) speakers feel able to do it, (2) speakers feel the need to show their abilities in front of their peers, and (3) speakers feel stronger and more powerful than their peers. Then, it can be indicated that the situation of the heart as a psychological factor causes student B's speech to violate politeness.

\section{Conclusion}

Based on the results of an analysis of 250 student utterances found 45 utterances violated the literal thimble; 10 speeches violating the thimble of generosity; 13 speeches violating the modesty thimble; 24 speeches breaking the thimble of acceptance; 26 speeches violate the approval thimble; and 7 speeches violating the thimble of sympathy. Violations are motivated 
by non-linguistic factors, namely social, geographical, social distance between speakers, family, and psychological. 


\section{References}

[1] Rohali. "Kesantunan Berbahasa sebagai Pilar Pendidikan Karakter: Perspektif Sosiopragmatik". Vol. I(1):26. Jurnal Pendidikan Karakter (2011)

[2] Zulaeha, I. "Pengembangan Model Pembelajaran Keterampilan Berbahasa Indonesia Berkonteks Multikultural". Vol. 12(1):104-105. Litera (2013)

[3] Ardhian, D. "Pendidikan Karakter Pekerti Bangsa melalui Strategi Kesantunan dalam Kesenian Ketoprak". Vol. 4:213-227. Prosiding (2012)

[4] Rokhman, F. "Sosiolinguistik: Suatu Pendekatan Pembelajaran Bahasa dalam Masyarakat Multikultural". Yogyakarta: Graha Ilmu (2013)

[5] Kumalasari, M. A., Rustono, dan Santoso, B. W. J. "Strategi Kesantunan Pemandu Acara Talkshow Kick Andy dan Mata Najwa di Metro TV”. Vol. 3(1):34-43. JP-BSI (2018)

[6] Astriani, A. S., Supratman, D., dan Pristiwati, R. "Pengaruh Kebiasaan Menonton Televisi Acara Informasi dan Pergaulan Teman Sebaya Terhadap Keterampilan Berbicara Siswa Kelas VIII MTs NU Ungaran". Vol. 2(1):1-5. JPBSI (2013)

[7] Widyawari, C.P., May, G., dan Zulaeha, I. "Representasi Ideologi dalam Tuturan Santun Para Pejabat Negara Pada Talk Show Mata Najwa". Vol. 5(1):9. Seloka. (2016)

[8] Cahyani, D. N. dan Rokhman. F. "Kesantunan Berbahasa Mahasiswa dalam Berinteraksi di Lingkungan Universitas Tidar: Kajian Sosiopragmatik". Vol. 6(1):44-52. Seloka (2017)

[9] Lestari, T. P., Rokhman, F. dan Indiatmoko, B. "Pelanggaran Prinsip Percakapan dan Parameter Pragmatik dalam Wacana Stand Up Comedy Dodit Mulyanto". Vol. 5(2):148-161. Seloka (2016)

[10] Alika, S. D. "Penyimpangan Prinsip Kesantunan Berbahasa dalam Interaksi Belajar Mengajar Bahasa Indonesia”. Vol.13(1):48-49. Jalabasa (2017) 